\title{
CROINTERVENT 2018
}

\section{Poštovane kolegice i poštovani kolege,}

Radna skupina za invazivnu i intervencijsku kardiologiju Hrvatskog kardiološkog društva organizira 8. kongres intervencijske kardiologije s međunarodnim sudjelovanjem - CROINTERVENT 2018, koji će se od 8. do 10. ožujka 2018. održati u hotelu Westin u Zagrebu.

Od zadnjeg kongresa protekle su dvije godine, što je u ovako dinamičnoj struci mnogo vremena, tijekom kojeg su se pojavili ili dodatno etablirali neki novi dijagnostički i intervencijski postupci. Također su u rutinsku kliničku praksu uvedeni novi lijekovi, a neki već prisutni dodatno su potvrdili svoju vrijednost u poboljšanju primarnog ishoda ili u prevenciji komplikacija kardiovaskularnih intervencija.

Cilj je kongresa prikazati trenutačno stanje i dosege suvremene intervencijske kardiologije, prepoznati i analizirati područja koja još uvijek nisu dovoljno istražena ili o njima nemamo usuglašena stajališta te naposljetku raspraviti o poteškoćama s kojima se svakodnevno susrećemo u kliničkoj praksi.

Kongres je, osim kardiolozima i specijalizantima kardiologije, namijenjen kardijalnim kirurzima, anesteziolozima, liječnicima drugih srodnih specijalnosti, liječnicima obiteljske medicine, kao i svima ostalima koji su profesionalno vezani za intervencijsko liječenje bolesti srca i krvnih žila.

U programu kongresa bit će zastupljena pozvana predavanja domaćih i stranih eminentnih stručnjaka, oralne te moderirane posterske prezentacije.

Osim razmjene teorijskoga znanja, i ovaj put će važan dio kongresa biti posvećen praktičnim aspektima intervencijske kardiologije, kako preko prijenosa intervencijskih zahvata uživo, tako i pokazivanjem već učinjenih procedura uz raspravu i komentare.

Pred vama je posebno izdanje službenog časopisa Hrvatskoga kardiološkog društva - Cardiologia Croatica, u kojemu objavljujemo sažetke odabranih originalnih radova sudionika, koji će na kongresu biti predstavljeni u obliku usmenih izlaganja i moderiranih postera.

S poštovanjem,

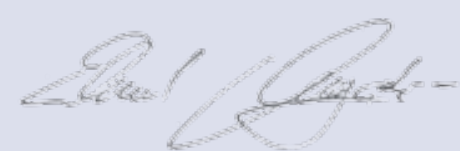

Doc. dr. sc. / Assistant Professor Eduard Margetić

Predsjednik Radne skupine za invazivnu i intervencijsku kardiologiju President, Working Group on Invasive and Interventional Cardiology Hrvatskoga kardiološkog društva / Croatian Cardiac Society

RECEIVED: February 4, 2018

E-mail: eduard.margetic@gmail.com | CITATION: Cardiol Croat. 2018;13(1-2):22.| https://doi.org/10.15836/ccar2018.22 ORCID: Eduard Margetić, https://orcid.org/0000-0001-9224-363X

\section{Dear Colleagues,}

The Working Group on Invasive and Interventional Cardiology of the Croatian Cardiac Society is organizing the $8^{\text {th }}$ Croatian Conference on Interventional Cardiology - CROINTERVENT 2018, which will take place in Hotel Westin, Zagreb, Croatia, on March 8-10, 2018

Since the last Conference, new diagnostic and interventional procedures emerged or have been established. New drugs have been introduced in routine clinical practice, and the value of some existing drugs for improving primary outcomes or preventing cardiovascular complications of cardiovascular interventions has been additionally confirmed

The aim of this event, in addition to demonstrating current clinical practice in interventional cardiology, is to discuss concerns and difficulties encountered in our daily practice.

Apart from cardiology and cardiology specialists, the CROINTERVENT 2018 is intended for cardiac surgeons, anesthesiologists, doctors of other specialties, and everyone else who is professionally associated with this important part of modern medicine.

The conference program will contain invited lectures and oral and moderated poster presentations. As before, a significant part of the conference will be dedicated to the practical side of interventional cardiology, both through transmitted "live cases" and presentation of already completed interventions with analysis and evaluation.

This Supplement of Cardiologia Croatica - the official journal of the Croatian Cardiac Society, consists of selected original contributions from our participants in the form of abstracts, which will be presented at the meeting in the form of oral presentations and moderated posters.

Sincerely yours, 